\title{
Marketing Aspects of Social Media Absorption in the Clothing Industry in the Light of Own Research
}

\author{
Łukasz Sułkowski, Dominika Kaczorowska-Spychalska \\ University of Social Sciences, Poland (Lodz) \\ lsulkowski@spoleczna.pl
}

\begin{abstract}
The process of exchange has been an integral part of life since the dawn of civilization, which means that marketing understood in a wide context as a contact between a seller and a market i.e. someone that is willing to buy something - is exactly as old as a notion of exchange (Otto, 2004). Subsequent stages in the process of its evolution have lead to its atomization and a need for exploration of optimal tools and working methods. The era of IT technology and related dynamic development of mobile devices and applications have contributed to an extensive development of social media that to an increasingly greater extent determine marketing activity of contemporary enterprises. Clothing industry is present virtually in every country and it is one of the most important sectors of the global economy. In case of some regions, both in a global and national perspective, it can be a factor that determines their development and further directions of evolution. The Łódź region that is the subject of the discussion presented below is a perfect example of that trend. The aim of the article is to identify the most popular methods and tools of social media marketing used by the main clothing enterprises from the Łódź region while taking into account indications for their further diffusion.
\end{abstract}

Keywords: Social media, marketing, e-community, consumer, clothing market

\section{Introduction}

The 21st century is an era of information technology and dynamic development of electronics which have become an integral part of contemporary economics and business. It forces entrepreneurs to be flexible, open to new ideas, to accept unconventional solutions as well as to undertake competition in the global market" (Wieczorek, 2003). Nowadays technology is a driving force for changes at the most basic level - it moves borders of possibilities and raises the level of customers' expectations: digitalization, networks of mutual contacts, combination of technologies cooperating in many spheres of life - from communication to entertainment, fast developing structures, short product lifecycles, mutual imitation, interactions (Fisk, 2009). The internet can be used for various applications: for e-mail and communication, for educational and scientific purposes, for business, for leisure, fir banking or for e-commerce (de Mooij, 2005). This is a subsequent stage in the process of technological evolution - social age - where IT technology modifies conditions of functioning of modern enterprises while forcing a need for adaptation and/or exploration of methods and tools of influencing the market. Its key element is a client who demands greater and greater integration of available technologies, applications and devices while expecting not only products but, first of all, extraordinary experiences and related emotions. Hypermedia space offers unlimited opportunities to create this and allows enterprises to multiply achieved results. Clothing market is undoubtedly one of the core areas of contemporary economy. Simultaneously, it is a very complex, multidimensional and demanding market. So implemented marketing activities have to consider e.g. seasonality, growing demands of customers, both relating to quality as well as to pricing policy, rationalization of purchasing decisions related to it, strong competition, etc. As a result, a systematic increase of a number of brand name outlets, a volume of online sales and intensification of marketing activities conducted through social media can be widely observed. The aim of the article is to identify and analyze methods and tools used in social media marketing by key clothing enterprises in the Łódź region

\section{Literature Review}

For the last fifty years the leading brands have included brands made by efficient factories and promoted by effective marketing. [...] all of a sudden, it turns out that these are not the oldest brands that develop at the fastest pace, as today we want novelties, a style, and first of all, something spectacular (Godin, 2010). Such 
opportunities are generated by social media, usually defined as a group of applications based on online solutions which rely on ideological and technological grounds of Web 2.0, which enable to create and exchange contents generated by users (Ludkowski, 2012). They include social networking sites, contents communities, discussion for a, blogs and vlogs, virtual game worlds or virtual social worlds. Social networking sites are used by more than a billion people all over the world. Every minute there appear more than 700 thousand new statuses and 0.5 million comments on Facebook. At the same time 25 hours of new video materials are added to YouTube and 100 thousand entries to twitter (Sadowski, 2013). Among different social media, Facebook with its more than 1 billion users is the most popular social networking platform not only among consumers but also among e-tailers. It is favored by the e-tailers over other social media, because it is a popular marketing channel that permits direct interaction with potential consumers and provides an unparalleled platform for consumers to publicly share evaluations of products (Nadeem, Andreini, Salo \& Laukkanen, 2015). Facebook is an extremely effective tool of global communications that claims to be a catalogue of the whole world population, or at least this part of our planet that has access to the Internet and that enables to establish connections with any people (Kirkpatrick, 2011). Obviously, it is not only Facebook, but also Twitter, LinkedIn, MySpace, Renren in China, Mixi in Japan, Odnoklassniki in Russia and hundreds of other networks (Shih, 2012). In the future they will provide tools to discover relations connecting them with other people and manifested by means of common behavior and interests (Kirkpatrick, 2011).

A systematic exploration of social media creates a chance to use their potential in diverse marketing activities of contemporary enterprises. That is why they are more and more often perceived not only through the prism of an eclectic definition but through specific ventures, tools, technological applications that meet specific functions and business objectives (Mazurek, 2012). They definitely revolutionized a way of communication between brands and customers while introducing an „all to all” discussion model. A key to success in this area is attractive, interesting and original content (Maciorowski, 2013). They are a new dimension of marketing communication that is based on Web 2.0 idea - the second generation of the Internet. Yet, the change does not concern only transformation of a monologue into a dialogue. This is a multilog - a much more complex level, where companies can talk to customers and customers to companies, but customers can also communicate with other customers - potential buyers and in a broader sense, to the whole society (Falls \& Deckers, 2013). As a result social media cease to be an instrument that serves only to build a brand image. They have a direct impact on sales. On average 30\% of customers makes a purchase under the influence of recommendation or information obtained from social media. In case of recipients representing Generation Y it is up to 50\% (Skażyński, 2014). Thanks to them it is possible to go beyond customers' expectations and to create a new, interactive reality where a customer is an active participant.

Companies that started to use social media in the period between 2007-2009, learned to use available tools and achieved stabilization of productivity. They became able to process information and use it in a practical and rational way. They just discovered that social marketing is real, can be relied on and its results can be measured (Falls \& Deckers, 2013). New online tools that are used in marketing are characterized by a short lifespan. Online reality, which changes continually, imposes very fast replacement of current methods and ways of conducting actions through new solutions while offering more and more advanced strategies of marketing tasks (Kaznowski, 2013). It results from intensification of competitors' activity as well as from increasing expectations of customers who demand more and more attractive and sophisticated experiences. They are critical and demanding toward applied solutions and they determine a natural process of social media evolution. Consequently, a role of video casts and mobile that are strictly connected with social media increases, and they let increase attractiveness of transmitted contents and effectiveness of conducted processes. New media users decide themselves when, where and what materials they want to obtain, what offers they want to use and how they want to intensify their experiences related to a company/brand. As a result contemporary marketing has become, both for companies/brands and for their clients, a philosophy of action whose driving force is IT technology. It is a peculiar multi-paradigm combining element of experiential marketing, relationship marketing, content marketing and e-marketing. It responds to a human desire of selfexpression, interpersonal bonds and a sense of belonging which are particularly important on the web (Shih, 2012).

Social media marketing is then a multidimensional set of informative actions conducted in order to satisfy individual and collective needs in the space of electronic market by means of information technology in order 
to gain, even a momentary competitive advantage and to achieve additional profits by organizations active not only in a virtual market (Chmielarz, 2005). This evolutionary approach to online space and its present users - creating such online environments where not only a gathering of Internet users occurs but also virtual communities that are based on knowledge, are built and modified as well as development of websites according to preferences of internauts (content personalization) (Dejnaka, 2013). Its main pillars include: information, interaction and visualization which enable it to become a part of online marketing activities which complement traditional promotion strategies used on the web. This is a form of viral marketing passed from mouth to mouth by Internet users and based on informing acquaintances about media, services or products that this person either loves or hates (Barefoot \& Szabo, 2011). Social media marketing enables enterprises to have constant informational presence on the web, endorse their identity, promote a corporate brand and a portfolio of product brands, to build a group of friendly people towards a product, accepting its „personality” and sharing a system of expressed values, presenting and explaining their market activities, taking a standpoint concerning important social and economic problems (Wiktor, 2013). It enables to improve the quality of customer service, test new products, reverse product placement or at last to conduct marketing research and other studies. It allows companies to reach a bigger number of people and implement, at a larger scale, a number of relations while increasing their productivity and effectiveness. In the process of its absorption a key role is assigned to an optimal correlation of its tools with individual phases of a purchase process. Before making a purchase a client looks for specific information that will facilitate to make a choice and make a right decision. The fundamental need in the pre-transaction level is a need to provide for trust in the product or firm (Walden, 2000). These can be contents transferred directly by the same company/brand as well as other users of the same product who want to share their opinions. Their reliability and usefulness are of crucial importance. While making a decision a client often rejects a so-called traditional model of purchase funnel, changing choices over and over and frequently coming to previously rejected variants. It is not restricted to elimination of subsequent alternatives that allow to satisfy needs but in a real time, they add or reject next options up to the moment of a final purchase. As a result, a client can look for information in social networking sites, corporate blogs, blogs and external vlogs or discussion fora. Content communities and virtual game worlds can also prove useful. In the after-sales phase the most important tools are such that let companies build relations with a client, verify a level of satisfaction with a purchase, conduct marketing research or look for innovations. Social networking sites and corporate blogs also prove very useful in this area. However, in case of social media marketing these objectives can be also achieved at each phase of a purchase process.

Communication between internauts is not a new phenomenon, however, the Web 2.0 technology made it possible for every person with access to the Internet to become a member of the international online community. The Web 2.0 technology has transformed passive Internet users into its co-designers (Barefoot \& Szabo, 2011). More and more often they become e-customers: buy more intensively on the Internet, spend more time online, they get in touch with friends and acquaintances on the net (Świerczyńska - Kaczor, 2012). They establish multisided relations and bonds while becoming a part of virtual communities. By means of the Internet and in real life customers find one another in global or local networks but it is Web 2.0, online applications that stimulate creativity of users and interactions between people, which create new bonds in the mainstream of human activity. [...] There are no physical barriers, no strange customers that ignore one another (Fisk, 2009). An important contribution of online social networks is that they have expanded the definition of community, which was once exclusively based on geographical, political or religious similarity to be based on any set similar of interests, products and brands (Cao, Knotts, Xu \& Chau, 2009). As a result ecommunity is created and it is understood as a community of the Internet users who actively use this communication platform to exchange information and messages connected with their common interests, beliefs and attitudes (Gustowski, 2012). They become a source of social life, a sense of belonging and social identity; these are groups of people who create social interaction, recognize the same norms of behavior or specific practices in the cyberspace (Sznajder, 2014). They are formed when a sufficient number of people continue public discussions for such a long time and with such emotional involvement so that networks of personal relations are created (Rheingold, 2000). They enable to do the same things that we do in real life they enable to express oneself, make friends, and ask questions, share ideas. [...] There is some space on the Internet where people feel safe, needed and where they willingly return (Gustowski, 2012). 
They are a kind of equivalent of primeval tribes where belonging was a reflection of a social status, let us survive, conditioned our behavior and attitudes. A tribe is a group of related people who are committed to a certain idea and one leader. It is necessary to have common interests and a way of communication" (Godin, 2010). Thanks to IT technology and mobile devices, possibilities to communicate in spatio-temporal context are unlimited and passions, hobbies, companies/brands or products offered by them become a reflection of motivation that decides on willingness to belong to a given e-community. As far as the development of social marketing is concerned the most important communities are those whose functioning is moderated by a company and that are related to consumption, a product or a brand. These communities become an increasingly crucial part of enterprise marketing strategies as they are a crucial channel of after-sales or promotional actions (Świerczyńska - Kaczor, 2012). No brand can exist without loyal customers who return and are willing to trust a company/brand again. Because of strong competition in e-commerce it is ineffective to treat all customers in the same way. Every customer is different, buying motives are different that is why a proper preparation of a good strategy and a plan of communication with customers requires to understand their intentions, current and future behavior, fears and inspirations (Piwowarczyk, 2014). There is more and more evidence that customers are driven by emotions. What get more important for them are experiences and incidents which will generate emotions. What one customer perceives through one's own perception model influences the image of a certain company/brand. A lot of information and events remain in the memory, they are not forgotten, and the only problem to solve is only a way of reaching these events, in other words, using a computer language to find an access path (Falkowski \& Tyszka, 2006). Having a general knowledge of a customer profile, their behavior and a decision-making process, it is necessary to understand premises for their presence in specific social media and expectations from them. It offers an opportunity for a thorough behavioral analysis while giving a free choice of optimal methods and tools that could increase the level of customers' involvement, build their relations and the level of awareness of a given brand. The strategy of social marketing built on their basis should be directed at, on the one hand, strengthening customer behavior desired by a company/brand through the increase of intensity and variety of used instruments. On the other hand, it should concern elimination and/or potential change of unwanted or troublesome habits. It regards both information materials and elements of interaction connected with entertainment and escapism while taking into account specificity of individual social media. It stimulates its own consumer e-community gathered around a company/brand while providing it with an added value and building their market advantage on the basis of it, because customer profitability is principally determined not by the costs of the product that the customer buys, but by the cost of managing customer relationship (Ryals, 2008).

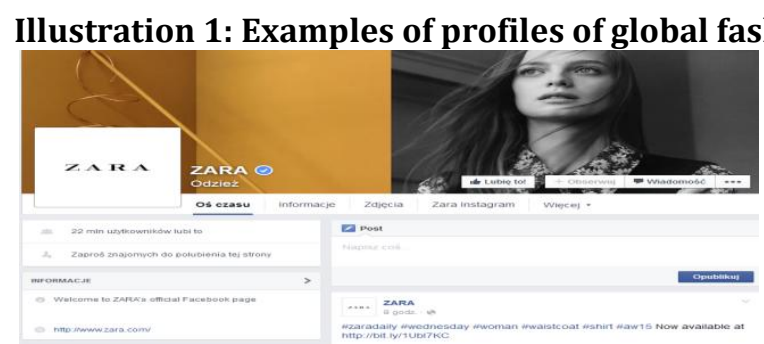

https://www.facebook.com/Zara [15.07.2015] [15.07.2015]

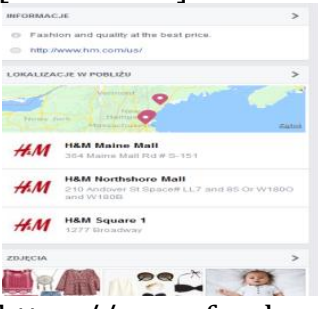

https://www.facebook.com/hmtheus?brand [15.07.2015] [15.07.2015]

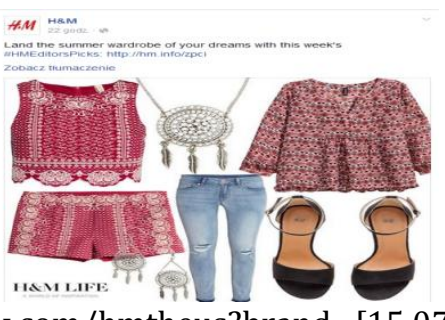

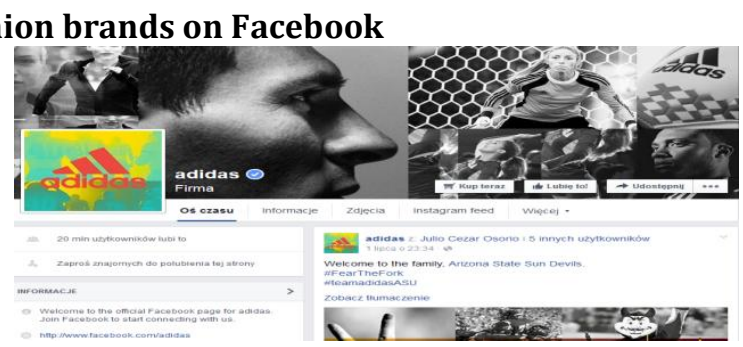

https://www.facebook.com/adidas

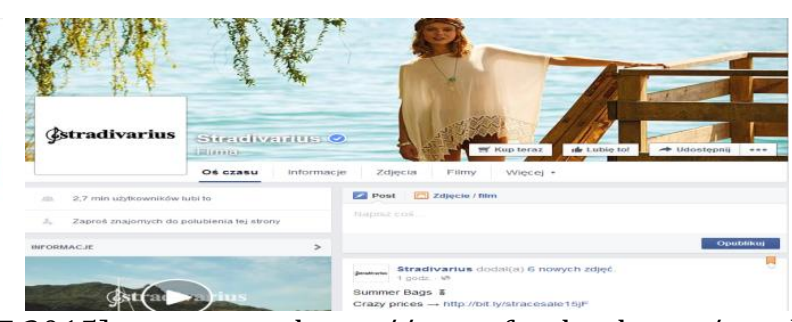

https://www.facebook.com/stradivas 
Participation in the life of online communities does not boil down to creating a website, putting a blog entry, asking questions or tweet publication. There is a widespread discussion about their prominent potential but it should not be generally believed that they are easy and fast (Evans, 2011). They are a much broader notion and require to adopt it at every single stage of implemented strategy of enterprise management. Social business is not only business that uses social media. Actually, it is a new era of cooperation conducted inside and outside a company, sharing knowledge about customers and constant implementation of changes based on that knowledge (Sadowski, 2013). Social media are a way of thinking and perceiving surrounding reality. However, these are the people who decide on their usefulness and possibilities of application to the process of building a market advantage. The Titanic effect that is frequently observed and that "consists in a situation when a company or a brand due to unswerving certainty of managers in their routine, superficial thinking about customers as if an old paradigm was enough to understand a market as well as quick adaptation to market conditions (Zaltman, 2008), becomes a barrier to enterprise development. Lack of openness to new concepts and abilities of holistic thinking, reluctance to adopt new solutions, ignoring what a customer expects on the level of a contact with a company/brand or, at last, lack of knowledge concerning evaluation of level of effectiveness of conducted activities, hinder optimal usage of opportunities that are currently generated by social media. As a result, it leads to disappointment, especially in case of excessive entrepreneurs' expectations of still a new technology. However, ignoring social media and pretending that they are only a manifestation of a fad, not necessarily adjusted to our possibilities, may soon prove a wrong decision. Clothing industry has not remained indifferent to challenges of new technologies and it intensively implements methods and tools of social media marketing. The observation of popular brands such as Zara, Stradivarius, H\&M, Carry, Reserved, Gap, Nike, Adidas, etc. shows that they are aware not only of benefits that social media bring, but also of threats related to their web presence.

In majority of cases well-known recognizable fashion brands treat social media as a platform of activities aimed at optimization of a communication process. They enable to promote a desired brand image among real and potential customers as well as to create multisided relations. They undertake more and more sophisticated strategies of social media marketing in order to increase brand awareness, website traffic and online sale. The key elements of this process include, first of all, social networking sites, internal blogs and external bloggers and vloggers that perform a function of trendsetters. The role of YouTube is also significantly growing as it allows to present a collection and outfit sets in an interactive way. However, the role of online fora in creating fashion and popularizing specific trends has decreased. Nowadays their function boils down to exchanging opinions between users of specific products about their quality, functional qualities and profitability of purchase. Such a choice of social media tools results first of all, from the fact that fashion and related clothing market are conditioned by emotions arising from dealing with individual brands and products offered by them. The purchase of specific products is a manifestation of our social status and a tool of creating and showing one's own, unique personality. Thanks to conducted non-standard promotional actions, numerous competitions, discussions, the involvement of social media users increases and they want to become a part of e-community connected with a specific fashion brand. The process of social media absorption by brands of clothing market resembles a model where every subsequent phase shows a higher level of involvement, both, of a company/brand and its clients, eventually leading to the growth of effectiveness and efficiency of an implemented strategy. It is a reflection of the model of "Five stages of the development of fashion e-tail web sites"

\section{Diagram 1: Five stages of the fashion development in social media}

STAGE FIVE:High experience, knowledge to maximize on- and offline business

STAGE FOUR: Integration of skills, processes and technology connected with social media

STAGE THREE: Develop value integration and creative e-community

STAGE TWO: Develop information competence in social media

STAGE ONE: pevelop a social media presence

Hines T., Bruce M., Fashion Marketing, Elsevier Ltd., Oxford, 2007, p 265

Such an approach enables to recognize a role of social media in a marketing strategy of clothing enterprises in a systemic way. It also allows companies/brands to systematically develop knowledge and competence 
related to hypermedia environment. The starting point is identification of methods and tools that enable effective presentation of a brand in social media. These include, first of all, multimedia elements and competitions that facilitate interaction and draw attention of a potential customer. Yet, they have to be systematically complemented with information that must be translated into customers' knowledge and growth of their interest in a certain brand. They can include, e.g. elements concerning the brand history, its products, practical aspects connected with using its products. As a result, a client is a subject of a specific education process, which is often reflected in a purchase process. This leads to the next stage that concentrates on integration of own e-community and development of a related market. A brand must become a part of its clients' life while sharing their values and approving of their inspirations. The last two stages of a discussed model refer, first of all, to the process of integration within a certain organization so that social media could become an element of organizational culture and a manifestation of its way of perceiving a contemporary market. Thanks to this the conducted activities within social media marketing are getting increasingly advanced, sophisticated and provide spectacular experiences and emotions while at the same time they let clothing companies/brands maximize profits.

\section{Methodology}

The analysis of the level of social media absorption in implemented marketing activities in clothing industry enterprises in the Łódź province has been conducted both, by quantitative research (online survey) and qualitative research (interviews, observation). It was due to the complexity of a discussed topic and difficulties connected with an explicit definition of indications deciding about the level of using social media marketing, its dimensions of development in an analyzed market sector and possibilities of further diffusion. The first element of conducted study was the identification of clothing enterprises from Łódź with a significant market position and a comparative analysis of their case studies. The evaluation concerned mainly:

- a choice of social media that were used by analyzed companies;

- methods and tools of conducted image-building activities;

- methods and tools aimed at building relations;

- the level of direct usage of social media in the after-sales process (social shopping);

- the range of using social media in the process of marketing research;

The conducted analysis was of explorative character and its aim was to understand the specific character of social media marketing in the analyzed market as well as the identification of factors determining a choice of individual social methods and tools. What significantly determines decisions concerning using social media in a marketing strategy are: a huge diversity of enterprises active in the market, both in terms of their size, financial potential, strategic objectives and technological capabilities, target market, etc.

\section{Results and Discussion}

Illustration 2: Selected fashion brands from Łódź region in social networking sites.

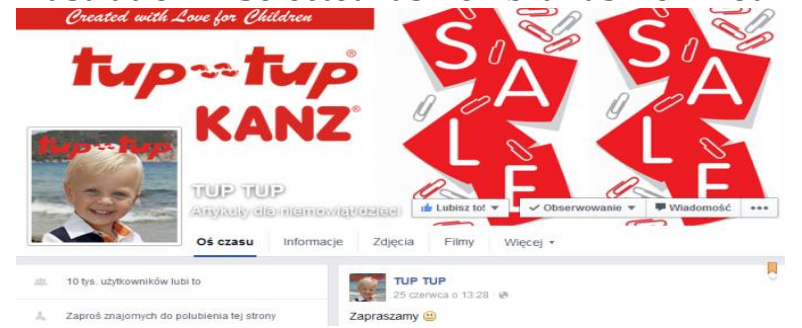

https://www.facebook.com/tuptup.poland [11.07.2015] [11.07.2015]

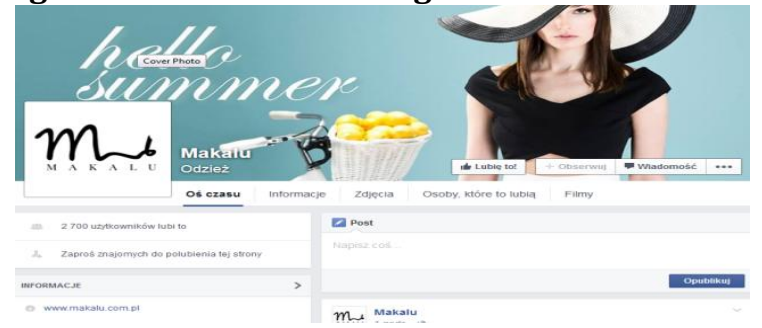

https://www.facebook.com/pages/Makalu 


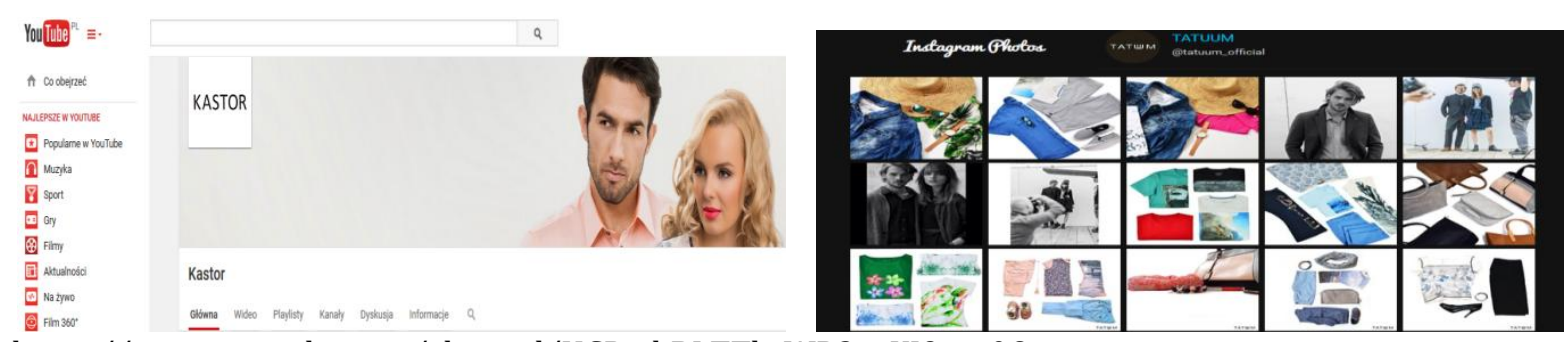

https://www.youtube.com/channel/UCPmkBLTTkrWP2znXI9v-q0Q

http://www.iphoneogram.com/u/597735964[11.07.2015]

The clothing market in Łódź region is an area with a great number of fashion enterprises that are active not only locally but also on an international and global scale. However, the conducted comparative analysis comprised only the companies with premises and factories in the Łódź province and the companies whose brand is recognizable, at least in the domestic market. Selected companies offer high quality products, a wide product range (multitude of available models, diverse colors, variety of sizes, offer for men and women, clothes and accessories). They have also a positive brand image and high quality of customer service, both in offline and online market. The comparative analysis included the following brands: Atelier Teresa Kopias, Gatta, Hexline, Kanz, Kastor, Makalu, Monnari, Próchnik, Tatuum, Tup Tup. The process of segmentation and a choice of target market show that some of these brands belong to luxurious brands and their products are targeted at very demanding customers. Conducted analysis indicated that all of these brands use social media in their marketing activities. They all have profiles in social networking sites. The only difference was a number and a choice of social media they are present in. All of them have a Facebook profile, which results from its dominant position in the Polish market. Some of them are also present in such portals as Twitter, Pinterest or Instagram. It can result from their growing popularity and willingness to reach a broader group of recipients as well as from the character of their users (e.g. Twitter in Poland is first of all, used by politicians, journalists, celebrities), which can positively influence the image of a certain brand.

Activities implemented by means of social networking sites generally boil down to information about new products, promotions and special offers. Competitions were also very common and they usually concerned visualization of selected models from a collection and sets proposed by its authors. This is definitely one of the most often applied tools of interaction that are directed at an increase of traffic in brand profile and evoking interest in it. Generally, brands enabled access to their profiles in social media through their own websites or online shops. In case of one brand access was also possible from the level of every subpage that was devoted to individual products, which allowed clients to personalize a conducted discussion in the context of specific models of offered clothes. Marketing activities that were implemented by means of various social portals in analyzed companies were of complementary nature. Brands did not confine themselves only to imitating contents presented before in individual social networking websites. Presented materials (text, photographs, films) dealt with new aspects and issues connected with a brand and its products. Thus a client was able to have access to various contents, both in terms of substance and elements related to fun and escapism. This is definitely a result of knowledge of individual brands about profiles of their customers and their expectations of social media. It must be noted that by means of social media brands referred to events that actually happen e.g. holidays (Easter, Christmas, Mother's Day). They referred also to important problems for a given community, such as ecology or help for specific foundations while stressing their usefulness for e-community integrated around them. They are also tools that enable to show that a brand is present in client's everyday life and participates in what matters to them. It consequently facilitates to build mutual relations and image-building activities.

However, none of the analyzed brands did not use social media in marketing research, research studies or reverse product placement. Customers' questions concerning individual models and their availability that were identified on a profile were often unanswered. It could be a result of lack of sufficient knowledge in this area, inability to moderate a discussion on a brand profile effectively as well as it can result from negligence in the process of customer service. In three cases brands ran their own company blog. Its main objective was to show a brand as an expert in clothing market and to build a competitive advantage through educating ecommunity related to it. Brands informed about their activities, participation in events in a fashion market 
and plans for the future. They referred to a fashion market and current trends as well as to everything that might interest a customer. What plays a crucial role here is a layout of presented contents. Moreover, two of the analyzed brands undertook cooperation with external bloggers. They were top bloggers of the Polish blogosphere. Their choice was not accidental; it was influenced by topics discussed in a blog that were strictly connected with a brand profile. What was also of crucial importance was that these bloggers are popular and are trusted by their readers although they are not top bloggers. Cooperation with them is continuous and is not restricted only to banner advertising or advertorials. Bloggers systematically put their posts that indirectly refer to brands cooperating with them. There is no information about seasonal sales or promotions. A brand is present thanks to posts concerning the history of clothing market, specific fabrics, rules of outfit composition, notions characteristic only for that market. Thus brands contribute to promoting knowledge concerning a clothing market while providing customers with an added value in a form of systematic, intriguing and unique knowledge.

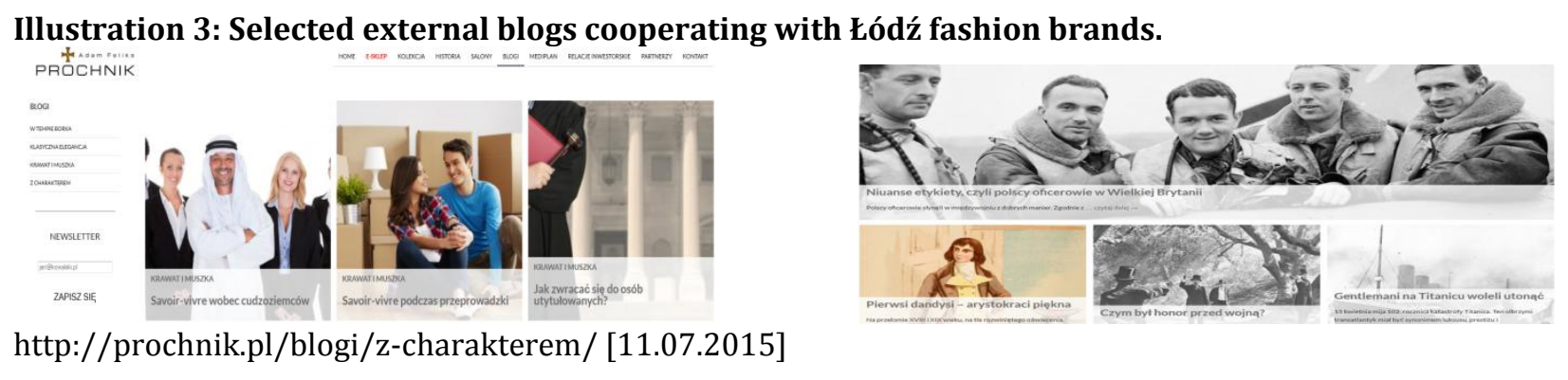

It was quite common for analyzed brands to take advantage of presenting their video materials on YouTube channel. They were mainly advertising spots, announcements of collections and shows, speeches by fashion experts concerning a given brand and presentations of new shops' openings. Undoubtedly, visual elements raised cognitive and esthetic values concerning a brand and/or presented products while evoking willingness to buy them. Thus YouTube allows fashion brands to achieve both, image-building and sales objectives. None of the analyzed brands used virtual community worlds or game worlds. One can assume that it results from the fact that they are not directly associated with this market sector. However, together with an increasing popularity and diversity of smart clothes and so-called wearable's i.e. devices that can be worn, interest in these social media tools in a clothing market will definitely increase in the near future.

\section{Conclusion}

The advent and strong popularization of social ideas observed recently should be considered an important event that changes a way organizations communicate with clients online and create a value of their brands. Due to strong visibility of social issues and articulation of benefits that can be achieved thanks to communities, more and more companies attempt to seize potential of online customers who discuss and create a unique information value that is impossible to achieve in any other way (Mazurek, 2008). The conducted comparative analysis and observation indicated in particular that clothing sector enterprises in the Łódź region do not fully use the marketing potential of social media. The most popular methods and tools of social media marketing are directed at image-building activities. Clothing companies/brands to a lesser extent engage in activities aimed at intensification of direct sales. It seems that the level and range of absorption of social media in this market depend on current experience in conducted strategies of social media marketing and related knowledge and competence as well as on the conviction of their effectiveness. Cooperation of clothing companies/brands with social media requires understanding of the essence and role of these media as well as their relevance for contemporary marketing. It is necessary to introduce some changes at the level of company management and to understand that social media are not only manifestation of new technologies but also an element of a new way of business thinking and implementation of market activities. The factors that become important include a size of a company, target market, or a specificity of offered clothes. They condition the level and range of used instruments of social media marketing. It should be supposed that in the near future the level and range of using social media marketing in clothing market will increase and move towards more and more innovative solutions, and towards engaging their recipients to a bigger extent. Today's communities are open to a deeper than before interaction with brands. Yet, one 
important condition must be met: a brand must offer a sufficient added value in return for devoted time show understanding of needs, really help, give valuable answers (Jurkiewicz, Majewska \& Sołtysińska, 2012).

\section{References}

Barefoot, D. \& Szabo, J. (2011). Znajomi na wagę złota. Oficyna Wolters Kluwer, Warszawa

Cao, J., Knotts, T., Xu, J. \& Chau, M. (2009). Word of Mouth Marketing through Online Social Networks. AMCIS

Chmielarz, W. (2005). Środowisko wirtualnego klienta, Wyd. Akademii Ekonomicznej, im O. Langego. Wrocław

Dejnaka, A. (2013). E-marketing, W: M. Dutko (red.), Biblia e-biznesu, Helion

Evans, L. (2011). Social Media Marketing, Helion, Gliwice

Falkowski, A. \& Tyszka, T. (2006). Psychologia zachowań konsumenckich. Gdańskie Wydawnictwo psychologiczne, Gdańsk

Falls, J. \& Deckers, E. (2013). Media społecznościowe bez ściemy. Helion. Gliwice

Fisk, P. (2009). Geniusz konsumenta. Oficyna Wolters Kluwer Business. Warszawa

Godin, S. (2010). Plemiona 2.0 - We Need You to Lead Us. Helion. Gliwice

Gustowski, W. (2012). Komunikacja w mediach społecznościowych, Novae Res

Hines, T. \& Bruce, M. (2007). Fashion Marketing, Elsevier Ltd. Oxford. p. 265

Kaplan, A. \& Haenlain, M. (2010). Users of the world unit! The challenges and opportunities of social media. Business Horizons, 53, 59-68

Kaznowski, A. (2013). Social media - społeczny wymiar Internetu, w: J. Królewski, P. Sala, e-marketing, PWN, Warszawa

Kirkpatrick, D. (2011). Efekt Facebooka. Oficyna Wolters Kluwer Business, Warszawa

Ludkowski, Ł. (2012). Social media po polsku, w: K. Budek (red.), Raport Social media w biznesie, Warszawa

Maciorowski, A. (2013). e-Marketing w praktyce. Wyd. Samo Sedno. Warszawa

Mazurek, G. (2008). Blogi i wirtualne społeczności - wykorzystanie w marketingu. Oficyna Wolters Kluwer Business. Warszawa

Mazurek, G. (2012). Znaczenie wirtualizacji marketingu w sieciowym kreowaniu wartości. Wyd. Poltext. Warszawa

de Mooij, M. (2005). Global Marketing and Advertising. Sage Publication. California

Nadeem, W., Andreini, D., Salo, J. \& Laukkanen T. (2015). Engaging consumers online through websites and social media. International Journal of Information Management, 35, 432

Otto, J. (2004). Marketing relacji - koncepcja i stosowanie. C.H.Beck. Warszawa

Piwowarczyk, M. (2014). Komunikacja marki. w: E-commerce manager t..II Zygadlewicz A. wyd. Fundacja Polak 2.0. Poznań

Rheingold, H. (2000). The Virtual Community. Homesteading on the Electronic Frontier, Cambridge Massachusetts, Introduction.

Ryals, L. (2008). Determining the indirect value of the customer, Journal of Marketing Management, 24, 847864

Sadowski, M. (2013). Rewolucja social media. Helion. Gliwice

Shih, C. (2012). Era Facebooka. Helion. Gliwice

Skarżyński, P. (2014). Customer Support: Dzisiaj i jutro, w: E-commerce manager t. II Zygadlewicz A. wyd. Fundacja Polak 2.0. Poznań

Sznajder, A. (2014). Technologie mobilne w marketingu. Oficyna Wolters Kluwer Business. Warszawa

Świerczyńska - Kaczor, U. (2012). e-Marketing, przedsiębiorstwa w społeczności wirtualnej. Difin. Warszawa

Walden, E. (2000), Some value proposition of online communities, Electronic Markets, 10(4), 2

Wieczorek, T. (2003). e - biznes: sieci komputerowe i technologie informacyjne. t. II. Wyższa Szkoła Biznesu w Dąbrowie Górniczej

Wiktor, J. W. (2013). Komunikacja marketingowa. PWN. Warszawa

Zaltman, G. (2008). Jak myślą klienci. Harvard Business Press. Dom Wydawniczy Rebis. Poznań 